\title{
Training and Development Techniques and Employee Performance in the Ministry of Labour and Social Protection, Nairobi City County, Kenya
}

\author{
Rhoda Nguta Kirimi ${ }^{1}$, Chrispen Maende ${ }^{2}$
}

\author{
Correspondent Author, School of Business, Kenyatta University, Kenya ${ }^{1}$
}

Department of Business Administration, School of Business, Kenyatta University, Kenya ${ }^{2}$

\begin{abstract}
\end{abstract}
Employees are major assets of any organization. The active role they play towards a company's success cannot be underestimated. As a result, equipping these unique assets through effective training becomes imperative in order to maximize the job performance. Despite the fact that training and development is well planned and systematic in the ministry of labour and social protection it still have issues of employees still not performing up to standard operating procedure in the work environment and labour turn over. Therefore, this study sought to determine the influence of training and development techniques on the performance of employees in the Ministry of labour and social protection. This study was guided by the following specific research objectives; to examine the influence of coaching, job rotation, role playing and apprenticeship on employee performance in the ministry of labour and social protection. This study was guided by goal setting theory and social exchange theory. The study used a descriptive design. The target population was 60 respondents comprising of 5 HRM managers and 10 supervisors and 45 Support staff. A census of 60 respondents was carried out. The study used questionnaires for the support staff and interviews for the HRM managers and supervisors. The qualitative data collected from the interviews was analysed using content analysis. Quantitative data was analyzed using descriptive statistics such as mean and standard deviation and presented using charts, figures, table and graphs. The study conducted a multiple regression analysis to test the relationship between independent variables and dependent variable. The study examined that coaching, job rotation, role playing and apprenticeship had a positive significant influence on employee performance. The study concludes that Coaching positively impacted employees careers as well as their lives by helping them to establish and take action towards achieving goals, Job rotation increased job satisfaction because employees were exposed to various work tasks that reduced constant physical or mental stress, which could create more motivation to continue in the position and reduce turnover, role playing brought together employees and or created a positive relationship among the employees in the work environment and apprenticeships are structured training programmes offered by the Ministry which gives their trainees a chance to work towards a qualification and offers them a vast experience that enable them to work elsewhere. The study recommends that The Ministry should devise clear goals that include benchmarks and deadlines, be prepared to help with time management, frame feedback in a forthright and positive manner, follow up on feedback, emphasize effort over ability and celebrate accomplishments. The Ministry should determine the critical positions or functions to include in the program, conduct a job analysis to determine the components of the job that are most important to learn during the job rotation, determine the ideal bench strength for each role, create job readiness assessments and an evaluation process, orient the employees, measure and reward success. The Ministry should identify the objective, need, experience of trainee, the issue or task for which role play method is selected. The focus should be on maximum involvement of individuals as participants so that an overall exposure and that The Ministry should have 
International Journal of Current Aspects, Volume 3, Issue II, 2019, PP 131-144, ISSN 2616-6976

[i]CAB

apprenticeship programs in every section which is in line the current needs of the organization and which comply with the ever changing organizational environment.

Key Words: Training and Development Techniques, Human Resource Management, Employee Performance.

DOI: 10.7176/ijcab.v3iII.11, urn: URN urn:nbn:de:0000ijcab.v3iII.116

Kirimi, R., \& Maende, C. (2019). Training and Development Techniques and Employee Performance in the Ministry of Labour and Social Protection, Nairobi City County, Kenya: A Case of Kenyan Government. International Journal of Current Aspects, 3(II), 131-144. http://journals.ijcab.org/journals/index.php/ijcab/article/view/11

\section{INTRODUCTION}

Workers are essentially assets to an organisation and the implications of more investment in them would raise expectations from them in terms of performance. Their improved skills and behaviour will give the organisation its competitive edge (Perry, 2015). Nel, Van Dyk, Haasbroek, Schultz, Sono and Werner (2014) observe that effective employee training leads to an increase in quality goods and services as a result of potentially fewer mistakes. The authors further observe that effective development programmes allow management to maintain a workforce that can adequately replace employees who may leave the company or who are moved to other areas. It also allows for employees to cope with newly developed technology, and ensures that adequate human resources are available for expansion into new areas. Employees are major assets of any organization. The active role they play towards a company's success cannot be underestimated. As a result, equipping these unique assets through effective training becomes imperative in order to maximize the job performance. Also position them to take on the challenges of the today's competitive business climate (Anderson, 2014). McConnell (2014) argues that policies are necessary to ensure that employee performance is evaluated, which in turn ensures that the appropriate training and development take place. With the help of the performance appraisal reports and findings, the organization can be able to identify development needs. Asad and Mahfod (2015) consider training and development as a planned process to modify attitude, knowledge or skill behavior through learning experiences to achieve effective performance in an activity or range of activities. Tannenbaum and Yukl (2012) argue that training and development improves the workforce competence in order to create a competitive advantage and contribute to organizational success. Corporations are offering a variety of training programs to meet their organizational needs.

Coaching is a form of development in which a supervisor supports the employees in achieving a specific professional goal by providing training and guidance (Whitworth, Sandhal, KimseyHouse \& Kimsey-House, 2014). Newly skilled individuals want more responsibilities and performance and coaching can hence support these individuals in achieving these changes. It is also a focus on lifelong learning and learning throughout one's life time is becoming increasingly vital in today's society (Jowett, 2012). Coaching supports many learning steps which lead to more employees to learn compared to traditional learning methods. Jorgensen, Davis, Kotowski, Aedla, and Dunning (2015) observe that one of the most effective methods for developing the horizon of employees is job rotation, especially human resource empowerment. Job rotation is considered as a method of job design by which employees learn job skills from different parts and relieve exhaustion due to repeated tasks by changing those. Gomez, Lorent and Cabrera (2014) define job rotation as working in different positions or in different situations at time 
periods which are classified based on a range of individual knowledge, skill and capability of employees. The main objective of job rotation is regularly shifting employees from a job to another in order to increase their motivation and enthusiasm.

A promising application of learning-by-doing is the usage of role plays. Role plays can be defined as an interactive process that involves participants assuming specified responsibilities that is, a role and performing specific tasks (Mercado, 2010). Because of the interactive and reflective process, role plays have the potential to promote sustainable changes in behaviour (Chen \& Martin, 2015). Thus, the identification of a successful training method is promising in saving company resources, increasing the chance of sustainability on their path towards process orientation and outbalancing associated costs. Apprenticeship training is a process by which people become skilled workers, through a combination of formal learning and long-term on-thejob training (Fox, 2012). Through apprenticeship, it is possible to learn a great deal about an industry in a rather short amount of time. Furthermore, all of the learning is hands-on rather than theoretical. According to Ball and John (2015) apprenticeship training helps employees to improve their skills, which will benefit the company in the long term. An apprenticeship encourages employees to think of their job as a career and to stay with the company for longer, which reduces recruitment costs. Offering an apprenticeship to an existing member of staff shows that organization sees their employee as an integral part of the workforce and are happy to invest in their future.

Employee performance is the outcome, accomplishment of work as well as the results achieved, which is linked to the strategic goals of the organization, customer satisfaction and economic contributions (Armstrong, 2010). Armstrong (2010) continues to indicate that performance has to be managed by taking systematic action to improve organizational, team and individual performance; where individual performance management process is associated with both financial and non- financial incentives. Organizations are obliged to meet the needs of their stakeholders, in this case employees, by rewarding their employee equitably according to their contribution (Serena, Muhammad \& Emran, 2012). Employee performance is measured using several methods based on the organizational preferences and the performance management system in practice over there. The performance management system defines the performance measures for employees, that is, the criteria to quantify and calculate the level of performance (Glaveli \& Karassavidou, 2011). Glaveli and Karassavidou (2011) also show that providing training and learning opportunities, innovation, and cost reductions stimulate performance. Together with these the competencies gained during training and development has a dramatic impact on job performance if transferred properly.

Employee performance is normally looked at in terms of outcomes. However, it can also be looked at in terms of behavior (Venkatraman \& Ramanujam, 2012). Frederick and Stephen (2010) stated that employee's performance is measured against the performance standards set by the organization. There are a number of measures that can be taken into consideration when measuring performance for example using of productivity, efficiency, effectiveness, quality and profitability measures. As noted by Draft (2015), it is the responsibility of the company managers to ensure that the organizations strive to and thus achieve high performance levels. This therefore implies that managers have to set the desired levels of performance for any periods in question. Employee performance is the set of employee behavior, results, and outcomes that come after completing the job tasks using certain competencies and that are measured through different metrics (Hameed \& Waheed, 2011). The most value adding 
possession available to any firm, business, or organization are its workforce. The performance on part of the workforce is the driving force behind the survival of any business firm. Further, Hameed and Waheed (2011) are of the view that well performing employees contribute to the efficiency and success of the organization. So, performance is crucial for the organizations and making strategies to improve performance and measuring it from time to time are a basic step that is to be taken. Without desired performance results, it is of no use continuing to invest in processes and projects.

\section{STATEMENT OF THE PROBLEM}

With the unpredictable business environment and intense business competition, the companies are required to reach certain standards by improving their performance to align with such great demands, an abundance of resources such as infrastructures or physical facilities are made meaningless without the support of qualified human resources that directly disrupt the continuity of the business operations (Asad \& Mahfod, 2015). Mohamud (2014) many public sector organizations engage in training of staff and have departments, units and sectors in charge of training and development. The need for staff training in the Ministry of Labour and social protection is accelerated by the gap that develops as a result of global technological changes that take place worldwide which affect day to day ministry's operations. MSSL has been practicing training since its beginning and particularly for the past five years. Several of its employee's staff including accounts clerks, secretaries, drivers, support staff for example have not qualified for any form of training nor is there any systematic process of staff development in place. However, despite the efforts done by Human Resource Management (HRM) department, the ministry has continuously encountered employees' performance challenges such as failure to meet targets and high labour turnover which is being informed by the fact that it has not been able to achieve its desired results. Mndeme (2011) study looked at the factors limiting effective implementation of training programmes in parastatal organizations in Tanzania but focused on electric supply company limited, Dar-es-Salaam. Mohamed (2013) did a study on factors affecting implementation of training Programs to the public institutions but focused on public service management. However, the study was qualitative in nature which does not guarantee conclusive findings due to a small sample involved. Githinji (2014) study looked at the effects of training on employee performance but focused on United Nations Support office for the African Union Mission in Somalia. However, the study used a cross-sectional research design in which the results are static and time bound. Kosgei (2015) examined challenges facing staff development and training. The study context was secondary schools in Kericho County. The aforementioned studies have shown a number of gaps in different areas but failed to address the research problem in the Ministry of Labour and Social Protection. Therefore, this study sought to investigate the influence of training and development techniques on employee performance in the Ministry of Labour and Social Protection in Nairobi City County, Kenya.

\section{OBJECTIVES OF THE STUDY}

The general objective of this study was to determine the influence of training and development techniques on the performance of employees in the Ministry of Labour and Social Protection in Nairobi City County, Kenya.

This study was guided by the following specific research objectives:

(i) To examine the influence of coaching on employee performance in the Ministry of Labour and Social Protection, Nairobi City County, Kenya. 
(ii) To find out how job rotation influences the employee performance in the Ministry of Labour and Social Protection, Nairobi City County, Kenya.

(iii) To establish the extent to which role playing influences employee performance in the Ministry of Labour and Social Protection, Nairobi City County, Kenya.

(iv) To identify the relationship between apprenticeship and employee performance in the Ministry of Labour and Social Protection, Nairobi City County, Kenya.

\section{THEORETICAL LITERATURE REVIEW 4.1 Goal Setting Theory}

The goal-setting theory is strongly affected by Ryan's (1970) assumption that human behavior is driven by objectives, so-called goals. Every relationship between a principle and an agent is characterized by information asymmetry (Jensen \& Meckling, 2006; Feess, 2004). Since the employer is not able to monitor the effort of the employees permanently, certain measures to motivate the staff have to be offered to the workforce. One suitable way to motivate is to set goals. The findings of numerous experimental studies show that goal-setting strongly influences human behavior and thus leads to changes in performance (Bandura \& Cervone, 2009); LaPorte $\&$ Nath, 2010)]. This holds true for varying tasks, different groups of participants and diverse experimental settings. Goal setting involves the conscious process of establishing levels of performance in order to obtain desirable outcomes. This goal setting theory simply states that the source of motivation is the desire and intention to reach a goal (Locke \& Latham, 2006). If individuals or teams find that their current performance is not achieving desired goals, they typically become motivated to increase effort or change their strategy. This theory is relevant to the study as it focuses on the assumption that learning is influenced by an individual's life goals. Goal-setting theory predicts that people will channel effort toward accomplishing their goals, which will in turn affect performance. It states that specific and challenging goals along with appropriate feedback contribute to higher and better task performance.

\subsection{Expectancy Theory}

This study will be guided by Expectancy theory proposed by Vroom (1964). Expectancy theory is a cognitive process theory of motivation that relies on the principle of belief that individuals the amount of effort put towards a certain task, the end results attained from it and the benefit acquired has a mutual relationship. Vroom (1964) observes that people's performance rely on person's characteristics such as personality, skills, knowledge, experience and abilities. It was also found that effort, performance and motivation are linked in a person's motivation. According to Greenberg (2011) expectancy theory provides guidelines for enhancing employee motivation by altering the individual's effort-to-performance expectancy, performance-to-reward expectancy, and reward valences. However, Hellriegel and Slocum (2011) indicate that leaders must make an effort to find out what their employees value as rewards (valence). They must also accurately assess employees' capabilities (expectancy) and make available all of the right resources to help employees be successful in their jobs. According to Vroom (1964) a person will conduct himself/herself or behave in a particular way because of the motivational factors vested on that particular behavior due to expected results out of the behavior. In other words, the person selected behavior is based on the motivation and is characterized by the appeal of the end results. This motivation can be categorized into three factors namely; Valence, expectancy and instrumentality. First, Valence is the person's strength for his/her favorite such as reward. For example employees will strive to have a positive outcome in their place of work. Second, 
expectancy is the likelihood that a specific act or attempt would result to a specific performance. These particular outcome achieved by an individual relies not just the options he/she makes rather on activities further than his/her control. This therefore, means that employee performance will rely on various factors and a chance in performance. Third, instrumentality is the likelihood that performance will result to the expected outcome. In other words a person will receive a reward the moment he/she fulfils his/her task. This theory will be relevant to the study as it proposes that an individual will behave or act in a certain way because they are motivated to select a specific behavior over other behaviors due to what they expect the result of that selected behavior will be. This means that a better employee performance will motivate them and hence lay loyalty towards the attainment of organization goals.

\subsection{Social Exchange Theory}

According to Emerson (1976) the dominant emphasis was the individual behavior of actors in interaction with one another. His primary aim was to explain fundamental processes of social behavior (power, conformity, status, leadership, and justice) from the ground up. Emerson (1976) believed that there was nothing that emerges in social groups that cannot be explained by propositions about individuals as individuals, together with the given condition that they happen to be interacting. Emerson (1976) defined social exchange as the exchange of activity, tangible or intangible, and more or less rewarding or costly, between at least two persons. Cost was viewed primarily in terms of alternative activities or opportunities foregone by the actors involved. Behavior is a function of payoffs, whether the payoffs are provided by the nonhuman environment or by other humans. Social exchange theory proposes that people might go beyond the simple economic transactional exchange and engage in a process of social exchange; through this process, people obtain the benefits of, and contribute to, social interaction, seeking to increase the outcomes that they positively value and decrease those that they negatively value (Molm, 2006). Coaching has been largely associated with a one-to-one process of helping others to improve, to grow and to get to a higher level of performance, by providing focused feedback, encouragement and raising awareness. This theory is relevant to the study as is used as a framework for predicting employee commitment, employee motivation and desire to remain with the organization. Coaching enables and empowers people, and it opens new opportunities for learning through which improved performance is attained.

\subsection{Resource Based View Theory}

This study was guided by Resource Based View theory as proposed by Barney (1991). Barney (1991) state that a firm is a collection of physical capital resources, human capital resources and organizational resources. The core premise of the resource-based view is that organizational resources and capabilities can vary significantly across firms, and that these differences can be stable. The theory focuses on the idea of costly-to-copy attributes of the firm as sources of business returns and the means to achieve superior performance and competitive advantage. Chandler (1990) indicates that organizational capabilities emanate from lower management, middle and top management and that a firm can gain competitive advantage when its resources and capabilities are used properly. The author further states that if these organization capabilities were carefully synchronized and assimilated it could achieve the economies of scale and scope needed to compete in national and international markets. Barney (1991) states that, "sustainable competitive advantage is derived from resources that are valuable, rare, imperfectly imitable (due to path-dependence, causal ambiguity, and social complexity), and no substitutable". A resourcebased view of the firm accepts that attributes related to past experiences, organizational culture 
and competences are critical for the success of the firm. This theory is relevant to the study because it shows that Ministry of Labour and Social Protection manage employee training and development on the basis of their resources and capabilities. A firm resource must, in addition, be valuable, rare, and imperfectly imitable and substitutable in order to be source of effective management of training and development programs. Resources may increase the company's capacity for efficient and effective management of employee training and development techniques and, thus, better employee performance.

\section{CONCEPTUAL FRAMEWORK}

Figure 1 shows the relationship between independent variables and dependent variable. The independent variables are coaching, job rotation, role playing and apprenticeship and the dependent variable is employee performance.

\section{Independent Variables}

\section{Coaching \\ - Individual needs \\ - Content \\ - Engagement level}

\section{Job Rotation}

- Orientation

- Career enhancement

- Job boredom/burnout

\section{Role Playing}

- Working condition

- Skill improvement

- Job competency

\section{Apprenticeship}

- Class room work

- Hands-on experience

- Job qualification

Figure 1: Conceptual Framework

\section{RESEARCH METHODOLOGY}

The study used a descriptive design. The research design adopted was suitable for the current research due to its quantitative nature and focus of determining the effect of the dimensions of training and development techniques on employee performance. In addition, the research data for this study was collected at only one point in time in order to enhance uniformity of the environmental context. The target population for this study was ministry of labour and social 
protection in Kenya. The respondents were 50 respondents comprising of 5 HRM managers and 45 support staff. A census of 50 respondents was carried out. This study used a questionnaire containing both open and close-ended questions so as to be able to capture more information from the respondents. This was possible because the sampled respondents are considered to understand that study questions which minimized interpretations of the questions thus making it cheaper and faster to collect data. The close-ended question was on 5-point likert scale. Likert scale is the most widely used approach to scaling responses in survey research. The researcher met the top level management to affirm the intention on carrying out the study on the organization and to clarify the significance of the study and the commitment required from the management. A self-administered questionnaire was dropped to each respondent and picked later after two weeks. The respondents were informed of the date the questionnaires be collected and also the researcher made a visit after one week to remind the respondents. The data obtained from the field was first edited and coded to present a meaning finding. The qualitative data collected from the open ended questions were analysed using content analysis. Quantitative data was analyzed using descriptive statistics such as mean and standard deviation and presented using charts, figures, table and graphs with the use of Statistical Package for Social Sciences (SPSS) version 17.0. The study used Analysis of Variance (ANOVA) to test the level of significant of the variables on the dependent variable at $95 \%$ level of significance. In addition, the study conducted a multiple regression analysis to test the relationship between independent variables and dependent variable.

\section{RESEARCH FINDINGS}

Regression analysis was carried out to show which among the independent variables were related to dependent variable. The findings are presented in Table 1.

Table 1: Regression Analysis

\begin{tabular}{|c|c|c|c|c|c|c|c|c|c|}
\hline \multirow[b]{2}{*}{$\begin{array}{l}\text { Mod } \\
\text { el }\end{array}$} & \multirow[b]{2}{*}{$\mathrm{R}$} & \multirow[b]{2}{*}{$\begin{array}{c}\mathrm{R} \\
\text { Square }\end{array}$} & \multirow[b]{2}{*}{$\begin{array}{l}\text { Adjusted R } \\
\text { Square }\end{array}$} & \multirow{2}{*}{$\begin{array}{l}\text { Std. Error } \\
\text { of the } \\
\text { Estimate }\end{array}$} & \multicolumn{5}{|c|}{ Change Statistics } \\
\hline & & & & & $\begin{array}{l}\text { R Square } \\
\text { Change }\end{array}$ & \begin{tabular}{|c|}
$\mathrm{F}$ \\
Change
\end{tabular} & df1 & df 2 & $\begin{array}{l}\text { Sig. F } \\
\text { Change }\end{array}$ \\
\hline 1 & $.678^{\mathrm{a}}$ & .803 & .800 & 1.184 & .139 & 3.221 & 4 & 48 & .00 \\
\hline
\end{tabular}

a. Predictors: (Constant), coaching, job rotation, role playing, apprenticeship

Table 1 shows a model summary that provides information about the regression line's ability to account for the total variation in the dependent variable. $\mathrm{R}^{2}$ which is the coefficient of determination, is the statistical measure of how close the data are to the fitted regression line which is $0.803(80.3 \%)$. The adjusted $\mathrm{R}^{2}$ which is the coefficient of multiple determinations, is the percent of the variance in the dependent explained uniquely or jointly by the independent variables $0.800(80.0 \%)$ of the changes in the employee performance variables could be attributed to the training and development. This means that other variables not studied contribute $20.0 \%$ of the employee performance.

Table 2: Analysis of Variance ANOVA 
International Journal of Current Aspects, Volume 3, Issue II, 2019, PP 131-144, ISSN 2616-6976 [iJCAB

\begin{tabular}{|ll|r|r|r|r|r|}
\hline & & & & & & \\
Model & & Sum of Squares & df & Mean Square & F & \multicolumn{1}{c|}{ Sig. } \\
\hline 1 & Regression & 18.059 & 4 & 2.004 & $\mathbf{6 . 0 7 4}$ & $.001^{\mathrm{a}}$ \\
& Residual & 112.130 & 44 & 2.347 & & \\
& Total & 130.188 & 48 & $\mathbf{4 . 3 5 1}$ & & \\
\hline
\end{tabular}

a. Predictors: (Constant), coaching, job rotation, role playing, apprenticeship

b. Dependent Variable: Employee Performance

The probability value of $0.001^{\mathrm{a}}$ indicates that the regression model was highly significant in predicting how coaching, job rotation, role playing, apprenticeship influenced implementation of employee performance in the Ministry of Labour and Social Protection, Nairobi City County, Kenya. The F calculated at 5\% level of significance was 6.074 since F calculated is greater than the F critical (value $=4.351$ ), this shows that the overall model was significant.

Table 3: Coefficients

\begin{tabular}{|c|c|c|c|c|c|}
\hline \multirow[b]{2}{*}{ Model } & \multicolumn{2}{|c|}{$\begin{array}{l}\text { Unstandardized } \\
\text { Coefficients }\end{array}$} & \multirow{2}{*}{$\begin{array}{c}\begin{array}{c}\text { Standardized } \\
\text { Coefficients }\end{array} \\
\text { Beta }\end{array}$} & \multirow[b]{2}{*}{$\mathrm{t}$} & \multirow[b]{2}{*}{ Sig. } \\
\hline & B & Std. Error & & & \\
\hline (Constant) & 0.492 & 1.172 & & 2.560 & .002 \\
\hline Coaching & 0.724 & .157 & 3.155 & 1.433 & .001 \\
\hline Job Rotation & 0.507 & .104 & 1.213 & 1.997 & .000 \\
\hline Role Playing & 0.674 & .147 & 5.057 & 4.504 & .001 \\
\hline Apprenticeship & 0.898 & .139 & 4.237 & 2.134 & .002 \\
\hline
\end{tabular}

As per the results, the equation $\left(\mathbf{Y}=\boldsymbol{\beta}_{\mathbf{0}}+\boldsymbol{\beta}_{\mathbf{1}} \mathbf{X}_{\mathbf{1}}+\boldsymbol{\beta}_{2} \mathbf{X}_{\mathbf{2}}+\boldsymbol{\beta}_{\mathbf{3}} \mathbf{X}_{\mathbf{3}}+\boldsymbol{\beta}_{\mathbf{4}} \mathbf{X}_{\mathbf{4}}+\boldsymbol{\varepsilon}\right)$ becomes: $\mathbf{Y}=\mathbf{0 . 4 9 2}+$ $0.724 X_{1}+0.507 X_{3}+0.674 X_{3}+\mathbf{0 . 8 9 8}_{4}$ where $Y=$ Employee Performance, $X_{1}=$ Coaching, $X_{2}=$ Job Rotation, $\mathrm{X}_{3}=$ Role Playing, ${ }_{4}=$ Apprenticeship.

The findings revealed that holding independent variables constant (coaching, job rotation, role playing, apprenticeship) to a constant zero, employee performance in the Ministry of Labour and Social Protection, Nairobi City County, Kenya would be at 49.2, a unit increase in coaching would lead to increase in employee performance in the Ministry of Labour and Social Protection, Nairobi City County, Kenya by a factor of 0.724, a unit increase in job rotation would lead to increase employee performance in the Ministry of Labour and Social Protection, Nairobi City County, Kenya by factor of 0.507 , a unit increase in role playing would lead to increase in employee performance in the Ministry of Labour and Social Protection, Nairobi City County, Kenya by a factor of 0.674 and a unit increase in apprenticeship would lead to increase in 
employee performance in the Ministry of Labour and Social Protection, Nairobi City County, Kenya by a factor of 0.898 .

The study revealed that coaching had a positive and significant effect on employee performance as indicated by $\mathrm{t}$-values $(\mathrm{t}=1.433, \mathrm{p}<0.05)$. Coaching is a form of development in which a supervisor supports the employees in achieving a specific professional goal by providing training and guidance (Whitworth, Sandhal, Kimsey-House \& Kimsey-House, 2014). The study found that job rotation had a positive and significant effect on employee performance as indicated by tvalues $(\mathrm{t}=1.997, \mathrm{p}<0.05)$. Jorgensen, Davis, Kotowski, Aedla, and Dunning (2015) observe that one of the most effective methods for developing the horizon of employees is job rotation, especially human resource empowerment. The study observed that role playing had a positive and significant effect on employee performance as indicated by $\mathrm{t}$-values $(\mathrm{t}=4.504, \mathrm{p}<0.05)$. Because of the interactive and reflective process, role plays have the potential to promote sustainable changes in behaviour (Chen \& Martin, 2015). The study examined that role playing had a positive and significant effect on employee performance as indicated by $\mathrm{t}$-values $(\mathrm{t}=2.134$, $\mathrm{p}<0.05)$. According to Ball and John (2015) apprenticeship training helps employees to improve their skills, which will benefit the company in the long term.

The researcher interviewed HRM managers. The respondents indicated that coaching gives the organization ability to establish and act towards achieving goals, increase engagement, gain a deeper learning, safe place to gain perspective, build personal awareness and support for improving specific skills. The respondents indicated that job rotation enables the employees to gain a wider skills, employees develop more skills in a wider array of positions. This provides job stability and equips them for better opportunities to earn promotions. The respondents indicated that role playing enables the employee build confidence, develop listening skills, be creative in solving problems, employees immediately apply content in a relevant, real world context, employees see the relevance of the content for handling real world situations and employees engage in higher order thinking and learn content in a deeper way. The respondents indicated that apprenticeships give young professionals the opportunity to showcase and develop their skills in a more challenging environment than experienced by most. Young professionals who participate in apprentice programs their confidence levels rise due to feeling like they are more a part of the profession and by giving the young professional an opportunity to use his or her applied skills, reveals strengths and weaknesses.

\section{CONCLUSIONS}

The study concludes that coaching positively impacted employees careers as well as their lives by helping them to establish and take action towards achieving goals. Coaching boosts confidence, improves work performance, and builds effective communication skills. Job rotation increased job satisfaction because employees were exposed to various work tasks that reduced constant physical or mental stress, which could create more motivation to continue in the position and reduce turnover. Role playing brought together employees and or created a positive relationship among the employees in the work environment. Allowed for assessment of how well employee understands and can apply what is learned, as indicated in their behavior. Apprenticeships are structured training programmes offered by the Ministry which gives their trainees a chance to work towards a qualification and offers them a vast experience that enable them to work else. 


\section{RECOMMENDATIONS}

The study recommends that the Ministry should devise clear goals that include benchmarks and deadlines, be prepared to help with time management, frame feedback in a forthright and positive manner, follow up on feedback, emphasize effort over ability and celebrate accomplishments. The Ministry should determine the critical positions or functions to include in the program, conduct a job analysis to determine the components of the job that are most important to learn during the job rotation, determine the ideal bench strength for each role, create job readiness assessments and an evaluation process, orient the employees, measure and reward success. The Ministry should identify the objective, need, experience of trainee, the issue or task for which role play method is selected. The focus should be on maximum involvement of individuals as participants so that an overall exposure and understanding of attitude, skills, knowledge, behavior, expectation, need for improvement, emotional stability and required competencies can be identified. The Ministry should have apprenticeship programs in every section which is in line the current needs of the organization and which comply with the ever changing organizational environment.

\section{REFERENCES}

Achi, S. E., \& Sleilati, E. (2016). The effect of coaching on employee performance in the human resource management field: the case of the Lebanese banking sector. International Journal of Trade and Global Markets, 9(2), 137-169.

Adjei, D. (2012). The impact of job rotation on employees' performance A case study: Utrak Financial Services Limited (Doctoral dissertation).

Anderson, A. (2003). Industrial psychology ( $3^{\text {rd }}$ Ed). New Jersey: Pearson Prentice Hall.

Armstrong, M. (2010). Armstrong's handbook of reward management practice: Improving performance through reward. Kogan Page Publishers.

Asad, M., \& Mahfod, J. (2015). Training and development and its impact on the employee's performance: A study of agility company-Kingdom of Bahrain. International Review of Management and Business Research, 4(3), 700.

Ball, K., \& John, D. (2015). Apprentice and trainee completion rates ( $2^{\text {nd }}$ ed). Adelaide: NCVER.

Bandura A, \& Cervone, D. (2009). Self-evaluative and self-efficacy mechanisms governing the motivational effects of goal systems. Journal of Personality and Social Psychology, 45(5), 1017-1028.

Borg, R. \& Gall, M. (1989). Educational Research: an Introduction. New York: Longman Inc

Cabus, S., \& Nagy, E. (2017). Performance of Hungarian firms: are apprentices an asset or a liability? Evidence from a unique matched employer-employee dataset (No. 1706). Institute of Economics, Centre for Economic and Regional Studies, Hungarian Academy of Sciences.

Chen, J. C., \& Martin, A. R. (2015). Role-play simulations as a transformative methodology in environmental education. Journal of Transformative Education, 13(1), 85-102.

Dhanraj, D., \& Parumasur, S. B. (2014). Perceptions of the Impact of Job Rotation on Employees, Productivity, the Organization and On Job Security. Corporate Ownership \& Control, 682.

Emerson, R. M. (1976). Social exchange theory. Annual review of sociology, 2(1), 335-362.

Feess E. (2004). A game-theoretical and application-oriented introduction. ( $3^{\text {rd }}$ ed). Marburg: Metropolis. 
Fox, J. (2012). Employee empowerment: an apprenticeship model (Doctoral dissertation, University of Hartford).

Frederick, B. A., \& Stephen, O. O. (2010). Teachers' perceptions of staff development programmes as it relates to teachers effectiveness: A study of rural primary schools in Kenya. Educational Research and Review, 5(1), 001-009.

Githinji, A. (2014). Effects of training on employee performance: a case study of United Nations Support Office for the African Union Mission in Somalia (Doctoral dissertation, United States International University-Africa).

Glaveli, N., \& Karassavidou, E. (2011). Exploring a possible route through which training affects organizational performance: the case of a Greek bank. The International Journal of Human Resource Management, 22(14), 2892-2923.

Gomez, P. J. Lorent, J. J. C. \& Cabrera, R. V. (2014). Training Practices and Organizational Learning Capability Relationships and Implications. Journal of European Industrial Training, 28, 234-256.

Hameed, A., \& Waheed, A. (2011). Employee development and its affect on employee performance: A conceptual framework. International Journal of Business and Social Science, 2(13), 224-229.

Hasluck, C., Hogarth, T., Baldauf, B., \& Briscoe, G. (2013). The net benefit to employer investment in apprenticeship training. Institute for Employment Research, University of Warwick.

Jensen, M. C, \& Meckling, W. H. (2006). Theory of the firm: Managerial behavior, agency costs and ownership structure. Journal of Financial Economics, 3(4), 305-360

Joma, M. A. R., Al-Abed, S. F. M., \& Nafi, J. S. I. (2010). The Effect of "Role-playing" on Students' Achievement and Motivation in the Governmental Schools of Bethlehem District in Palestine.

Jorgensen, M. Davis, K. Kotowski, S. Aedla, P. \& Dunning, K. (2015). Characteristics of Job Rotation in the Midwest US Manufacturing Sector. Ergonomics, 48, 1721-1733

Jowett, S. (2012). An investigation into the impact of coach leadership and coach-athlete relationship on group cohesion. Group Dynamics: Theory, Research, and Practice, 8(4) 302-311

Kampkotter, P., Harbring, C., \& Sliwka, D. (2016). Job rotation and employee performance evidence from a longitudinal study in the financial services industry. The International Journal of Human Resource Management, 1(1), 21-25

Kaymaz, K. (2010). The Effects of Job Rotation Practices on Motivation: A Research on Managers in the Automotive Organizations. Business and Economics Research Journal, l(3), 69.

Kombo D. K. \& Tromp, K. (2006). Proposal and Thesis Writing - A Production: Nairobi: Paulines Publications Africa.

Kosgei, K. K. (2015). Challenges facing staff development and training: A survey of secondary schools in Kericho County. International Journal of Humanities and Social Science Invention, 4(2), 34-47.

LaPorte, R. E, \& Nath, R. (2010). Role of performance goals in prose learning. Journal of Educational Psychology, 68(3), 260-264.

Leyer, M., Hirzel, A. K., \& Moormann, J. (2015). Effectiveness of Role Plays on Processoriented Behaviour in Daily Work Practices: An Analysis in the Financial Services Sector. In ECIS. 
International Journal of Current Aspects, Volume 3, Issue II, 2019, PP 131-144, ISSN 2616-6976

iJCAB

Locke, E. A. (2011). Motivation through conscious goal setting. Applied and Preventive Psychology, 5(2), 117-124

Locke, E. A., \& Latham, G. P. (2006). New directions in goal-setting theory. Current Directions in Psychological Science, 15(5), 265-268.

McConnell1, R. C. (2014). Managing employee performance. Journal of Health Care Management, 23(3):273-283

Mercado, S. A. (2010). Pre-managerial business education: A role for role plays? Journal of Further and Higher Education, 24(1), 117-126.

Mndeme, I. S. (2011). Factors Limiting Effective Implementation Of Training Programmes In Parastatal Organizations In Tanzania: A Case Study of Tanzania Electric Supply Company Limited, Dar-Es-Salaam And Coast Zone (Doctoral dissertation, The Open University of Tanzania).

Mohamed, A. (2013). Factors affecting implementation of training Programs to the public institutions: a case of President's office, public service management (Doctoral dissertation, Mzumbe University).

Mohamud, A. (2014). The effect of Training on Employee performance in Public Sector Organization in Kenya. The case of NHIF Machakos County. Unpublished Master Thesis, University of Nairobi.

Mohrenweiser, J. (2010). The causes and consequences of apprenticeship training. an economic and econometric analysis. Retrieved from http://edudoc.ch/record/96567/files/zu11047.pdf.

Molm, L. (2006). The Social Exchange Framework. In Burke, P. (ed.), Contemporary Social Psychological Theories Stanford, CA: Stanford University Press

Mugenda O. \& Mugenda, A. (2003). Research Methods: Quantitative and Qualitative Approaches. Nairobi: Acts press.

Munyai, N. N. (2011). Effect of role-play as a formative assessment technique on job performance (Doctoral dissertation).

Muriithi, C. W. (2016). Effect of Coaching On Employee Performance in Commercial Banks: A Case of Standard Chartered Bank Kenya Limited (Doctoral dissertation, United States International University-Africa).

Mwangi, Z. K. (2018). Effect Of Coaching On Employee Performance In State Corporations In Kenya. Strategic Journal of Business \& Change Management, 5(1).

Nel, P.S., Van Dyk, P.S., Hassbroek, G.D., Schultz, H.B., Sono, T. \& Werner, A. (2014). Human resources management, $\left(6^{\text {th }}\right.$ ed) Cape Town: Oxford University Press.

Orodho J. A. (2005). Techniques of Writing Research Proposals and Reports in Education and Social Sciences. Nairobi: Masola Publishers.

Owusu-Acheampong, E. (2015). Examining the Relationship between Employees/Apprentices Human Capital on their Performance in Small Scale Businesses in the Sekondi-Takoradi Metropolis. International Journal of Small Business and Entrepreneurship Research, 3(1), 1-9.

Perry, B. (2015). Organizational management and information systems, Oxford: Elsevier

Pousa, C., \& Mathieu, A. (2014). The influence of coaching on employee performance: Results from two international quantitative studies. Performance Improvement Quarterly, 27(3), $75-92$.

Ryan, T. A. (1970). Intentional behavior. New York: Ronald Press. 
Salih, M. O. I., \& Al, A. B. A. N. Y. (2017). Job Rotation \& Its Impact on employees' Performance: An Empirical Study among Employees at Red Sea University, Sudan. International Journal of Scientific Research and Management, 5(7), 6181-6184.

Serena, A, Muhammad, K. S., \& Emran, A. (2012). The impact of rewards on employee performance in commercial banks of Bangladesh: An Empirical Study. IOSR Journal of Business and Management, 6(2), 9-15

Setiawati, L., \& Riyanto, B. N. (2011). The importance of Apprenticeship Training Program as the backbone of High Value Leather Products Industries At Tanggulangin Sidoarjo Indonesia. In $2^{\text {nd }}$ International Conference on Education and Management Technology IPEDR vol (Vol. 13).

Tannenbaum, S. I., \& Yukl, G. (2012). Training and development in work organizations. Annual review of psychology, 43(1), 399-441.

Taruru, I., Keriko, J. M., Ombui, K., Karanja, K., \& Tirimba, O. I. (2015). Effects of coaching programmes on employee performance in business process outsourcing subsector of Nairobi city county, Kenya. International Journal of Scientific and Research Publications.

Tarus, B. K. (2014). Effects of Job Rotation Strategy on High Performance Workplace, in Lake Victoria North Water Services Board, Kenya. International Journal of Business and Management, 9(11), 139.

Venkatraman, N., \& Ramanujam, V. (2012). Measurement of business economic performance: an examination of method convergence. Journal of management Development, 13(1), 109 $-222$

Whitworth, L., Sandhal, P., Kimsey-House, H., \& Kimsey-House, K. (2014). Co-active coaching: New skills for coaching people toward success in work and life. Davies-Black.

This is an open-access article published and distributed under the terms and conditions of the $(\mathrm{cc})$ EY $\quad$ Creative Commons Attribution 4.0 International License of United States unless otherwise stated. Access, citation and distribution of this article is allowed with full recognition of the authors and the source.

Authors seeking to publish with an International Peer Reviewed Journal should consider www.ijcab.org by writing to the Editor at editor@ijcab.org. List of our Journals are Available at www.ijcab.org/journals 